\title{
RISK DIVERSIFICATION IN ASEAN-5 FINANCIAL MARKETS: AN EMPIRICAL ANALYSIS IN THE CONTEXT OF THE GLOBAL PANDEMIC (COVID-19)
}

\author{
Rita Silva ${ }^{1}$ \\ Rui Dias ${ }^{2}$ \\ Paula Heliodoro ${ }^{3}$ \\ Paulo Alexandre ${ }^{4}$
}

DOI: https://doi.org/10.31410/LIMEN.S.P.2020.15

\begin{abstract}
The World Health Organization (WHO) has designated the new coronavirus infection as a global pandemic, based on the risk of contagion, and the number of confirmed cases in more than 195 countries. COVID-19 has an intense impact on the global economy, resulting from uncertainty and pessimism, with adverse effects on financial markets. Due to these events, this essay aims to estimate if the portfolio's diversification is feasible in the financial markets of Indonesia, Malaysia, Philippines, Singapore, and Thailand (ASEAN-5), in the context of the global pandemic (Covid-19), regarding the period of July 1, 2019, to July 22, 2020. To achieve such an analysis, is intended to provide answers for two questions, namely: $i$ ) the global pandemic (Covid-19) has accentuated financial integration between the ASEAN-5 markets? ii) If so, can the persistence of returns affect the risk diversification of portfolios? The results obtained suggest that those regional markets present accentuated levels of integration. However, the Singapore's stock market index does not show any level of integration, indicating that the implementation of portfolio's diversification strategies can be considered; however, the same can no longer be evident for the other ASEAN-5 markets. Additionally, we verified that the ASEAN-5 markets indicate persistence in returns, that is, the presence of accentuated long memories, except for the Singapore market (SGX). These findings show that prices do not fully reflect the information available and that changes in prices are not independent and identically distributed. This situation is found for investors, since some returns can be expected, creating opportunities for arbitrage and abnormal earnings. Corroborating the trendless cross-correlation coefficients $\left(\lambda_{D C C A}\right)$, proven evidence coefficients, mostly, suggest the existence of risk transmission between markets. In conclusion, the authors seek that the implementation of an efficient diversification strategy for portfolios requires agreement with the controversial application. These conclusions also open space for the regulators of these regional markets to take measures to ensure better information between these markets and international markets.
\end{abstract}

Keywords: ASEAN 5, Covid-19, Financial integration, Portfolio risk diversification.

1 Escola Superior de Ciências Empresariais - Instituto Politécnico de Setúbal, Portugal

2 Escola Superior de Ciências Empresariais - Instituto Politécnico de Setúbal \& CEFAGE, Universidade de Évora, Portugal

Escola Superior de Ciências Empresariais - Instituto Politécnico de Setúbal, Portugal

Escola Superior de Ciências Empresariais - Instituto Politécnico de Setúbal, Portugal 


\section{INTRODUCTION}

7 he outbreak of COVID-19 has caused global concern. On January 30, WHO declared it a global health emergency. The natural spread of this virus has created uncertainty in the worldwide population. This epidemic has also changed people's lifestyles; caused job losses and threatened the livelihood of millions of people as companies closed to control the spread of the virus. Globally, the quick spread of the coronavirus (Covid-19) has had devastating impacts on the global economy, and consequently on financial markets worldwide (Zhang, Hu, and Ji, 2020; Ali, Alam, and Rizvi, 2020).

Globalization has accentuated the synchronization between international financial markets, which has shown that the correlation between international financial markets has increased, particularly in periods of extreme volatility. If a given stock market is strongly linked to the stock market of another country, the financial stability of the former depends, in part, on the financial stability of the latter. For this reason, a close or strong link between markets increases levels of vulnerability to external shocks and, as a result, influences the economic conditions and welfare levels of the respective countries, as well as the efficiency of the market itself (Alexandre, Dias, and Heliodoro, 2020a, 2020b; Alexandre, Heliodoro, and Dias, 2019; Dias et al., 2020; Dias and Carvalho, 2020; Dias, da Silva, and Dionísio, 2019; Dias, Heliodoro, and Alexandre, 2020a, 2019; Dias, Heliodoro, Alexandre, Santos, and Farinha, 2021; Dias, Heliodoro, Teixeira, and Godinho, 2020; Dias, Pardal, Teixeira, and Machová, 2020; Dias, Heliodoro, Alexandre, and Vasco, 2020b; Dias and Pereira, 2021; Heliodoro, P., Dias, R., Alexandre, P., and Vasco, 2020; Heliodoro, Dias, and Alexandre, 2020; Pardal, P., Dias, R., Šuleř, P., Teixeira, N., and Krulický, 2020; Santos and Dias, 2020).

The integration of global equity markets has been a topic that has been extensively analysed in recent decades, especially after the fall of stock exchanges, during the global financial crisis. Most studies have concentrated on developed markets, such as the USA, Western Europe and Japan, to the detriment of other regional markets, such as ASEAN-5 markets (Ben Rejeb and Boughrara, 2015; Dias, da Silva, and Dionísio, 2019).

The ASEAN represents the fourth largest commercial region in the world, the countries that makeup ASEAN-5 constitute 72.8\% of ASEAN's population and 95.1\% of its GDP. ASEAN's average annual rate of economic growth has been approximately $5 \%$ over the past two decades. China's recent economic growth and the signing of the Free Trade Agreement with ASEAN for the development of a single market has increased economic integration between ASEAN markets (Petri, Plummer and Zhai, 2012; Chachavalpongpun, 2018).

This investigation will test whether portfolio diversification is feasible in the financial markets of Indonesia, Malaysia, the Philippines, Singapore, and Thailand (ASEAN-5), in the context of the global pandemic (Covid-19), from July 1, 2019, to July 22, 2020. To achieve such an analysis, we intend to answer two questions, namely whether: i) the global pandemic (Covid19) has accentuated financial integration between ASEAN-5 markets? ii) If so, can the persistence of returns undermine portfolio diversification? The results suggest that these regional markets have marked levels of integration, except for the Singapore stock market. Additionally, we found that the ASEAN-5 markets indicate persistence in returns, that is, the presence of long accentuated memories, except for the Singapore market (SGX). The trendless cross-correlation coefficients $\left(\lambda_{\text {DCCA }}\right)$, show significant coefficients, mostly, suggesting the existence of risk transmission between markets. These results may call into question the implementation of efficient portfolio diversification strategies in these regional markets. 
This research makes some contributions to the literature, namely the study on the diversification of portfolios in these regional markets (ASEAN-5), during the pandemic outbreak (Covid-19). As far as we know, this is the first study to analyse these financial markets in isolation. The preference for these ASEAN 5 financial markets can, therefore, be explained by the fact that they have unstable, rapidly developing economies and are thus linked by cultural heritage and some similar economic conditions. Besides that, after the recent financial crisis of 2008 in emerging international markets, and those of ASEAN-5, they have become a famous investment destination. In this context and bearing in mind the massive inflows of capital, it is of great importance to understand the interdependencies and links between these regional financial markets. However, there are recent studies that have investigated the impact of the global pandemic (Covid-19) on financial markets, namely studies by authors Ali, Alam, and Rizvi (2020), Sansa (2020), He, Liu, Wang, and Yu (2020), but the approach was different and fell on other financial markets.

This essay is structured in 5 sections. Section 2 presents the Literature Review regarding articles on integration in the financial markets, section 3 describes the methodology and the data, section 4 shows the results; finally, in section 5 the general conclusions of the work are presented.

\section{LITERATURE REVIEW}

The understanding of the international links between stock markets and investigation of the occurrence of financial integration phenomena, in the context of stock market crashes, is essential for investors, investment fund managers and academics in several aspects, namely in the diversification of portfolios in the context of international (Dias, da Silva, and Dionísio, 2019).

Oh et al. (2010) argue that the benefits of portfolio diversification in the ASEAN-5 markets are reduced as the markets increase their integration in the post-crisis. Auer and Mehrotra (2014) claim that the increase in integration caused moving emotions. The authors point out that true integration through the supply chain is essential for asset price dynamics in the AsiaPacific region. However, authors Boubakri and Guillaumin (2015) develop that East Asian stock markets were partially segmented, except for Japan, until 2008. However, the last few years have been characterised by a marked level of integration financial.

Hung (2019), Wu (2019), Sanusi, Singagerda, and Septarina (2019), investigated risk diversification in Asian markets. Hung (2019) shows that the volatility of the Chinese market has had a significant impact on other markets, suggesting that the stock markets are more integrated due to the financial crisis. However, the authors Sanusi, Singagerda, and Septarina (2019) demonstrate the presence of long memories in ASEAN markets, which may be beneficial for investors, as these markets show some predictability. Wu (2019) suggests that integration is not accentuated in the stock markets of East and Southeast Asia, although the governments of that region are promoting financial integration in these regional markets.

Gulzar et al. (2019), Moagar-Poladian, Clichici, and Stanciu (2019), Jawadi, Chlibi, and Cheffou (2019), Salisu, Ndako, Adediran, and Swaray (2020) analysed the integration in the financial markets and tested the diversification hypothesis of wallets. Gulzar et al. (2019) examined the financial markets of India, China, Pakistan, Malaysia, Russia, South Korea, and the U.S., and evidenced the existence of long-term integration between the U.S. market and emerging stock markets, in the CFG post. Moagar-Poladian, Clichici, and Stanciu (2019) show that the Central and Eastern European markets have shown a significant level of integration 
during the European financial crisis. However, the authors Jawadi, Chlibi, and Cheffou (2019) show that the MENA and BRIC's markets are segmented with the North American market, while the G6 markets demonstrate integration. Salisu, Ndako, Adediran, and Swaray (2020) analysed integration in Islamic markets, and showed that markets are integrated, and that this behaviour can be influenced by global economic conditions.

Caporale, Gil-Alana, and Poza (2020), Milos, Hatiegan, Milos, Barna, and Botoc (2020) analysed the stock markets in Central Europe. Caporale, Gil-Alana, and Poza (2020) suggest that these regional markets have marked levels of integration, which may jeopardize the portfolio's diversification. Milos, Hatiegan, Milos, Barna, and Botoc (2020) verified the presence of long memories and long-term correlations, showing that the inefficient stock markets, in their weak form, have not yet reached a mature stage of development.

In summary, this work aims to contribute to the provision of information to investors and regulators in the ASEAN-5 markets, where individual and institutional investors seek to efficiently diversify their portfolios, in a period of uncertainty and lack of confidence due to the global pandemic (Covid-19).

\section{METHODOLOGY}

\section{DATA}

For this study, we used daily data on prices' indices of Indonesia, Malaysia, Thailand, Singapore, and the Philippines markets, in the period from July 1, 2019, to July 22, 2020. The data was obtained from the Thomson Reuters database and is quoted in a local currency, to mitigate distortions in exchange rates.

Table 1. The name of countries and their indices used in this paper.

\begin{tabular}{|l|c|}
\hline \multicolumn{1}{|c|}{ Country / Region name } & Index \\
\hline INDONESIA / ASEAN-5 & JKSE \\
\hline MALAYSIA / ASEAN-5 & KLSE \\
\hline PHILIPPINES / ASEAN-5 & PSI \\
\hline SINGAPORE / ASEAN-5 & SGX \\
\hline THAILAND / ASEAN-5 & SET \\
\hline
\end{tabular}

Source: Own elaboration.

\section{MODEL}

To assess the integration between the ASEAN-5 financial markets, we use the methodology of Gregory and Hansen (1996) that identifies breaks in structure. To validate results, we will use the method Detrended Fluctuation Analysis (DFA), and Detrended Cross-Correlation Analysis (DCCA). DFA is a method of analysis that examines the dependence of the temporal on nonstationary data series. This technique, assuming that the time series are nonstationary, avoids spurious results when the analysis focuses on the relationships of the data series in the long run. The DFA has the following interpretation: $0<\alpha<0,5$ : anti-persistent series; $\alpha=$ 0,5 series has a random walk; $0,5<\alpha<1$ persistent series. The function of this technique is to examine the relationship between the $x_{k}$ and $x_{k+t}$ values at different times (Guedes et al., 2018; Dias, da Silva, and Dionísio, 2019 Alexandre, Dias, and Heliodoro, 2020; Dias, Heliodoro, Alexandre, Santos, and Farinha, 2021; Dias, Heliodoro, and Alexandre, 2020; Dias, Heliodoro, Alexandre, and Vasco, 2020; Dias, Pardal, Teixeira, and Machová, 2020). The 
Zebende (2011) non-trend cross-correlation coefficient is a method for quantifying the level of cross-correlation between two nonstationary time series. The coefficient is based on the DFA (Peng et al., 1994) and DCCA (Podobnik and Stanley, 2008) methods. The cross-correlation coefficient depends on the length of the box $s$ (time scale). One of the advantages of this crosscorrelation coefficient is centred on the possibility of measuring the correlations between two nonstationary time series at different time scales. The DCCA cross-correlation coefficient varies within the range $-1 \leq \rho D C C A \leq 1$, logically 1 means perfect cross-correlation, -1 means perfect anti-cross-correlation and 0 means that there is no correlation (Podobnik and Stanley, 2008).

\section{RESULTS}

Figure 1 shows the fluctuations, in levels, of the ASEAN-5 financial markets. The sample comprises the time horizon from July 1, 2019, to July 22, 2020, which is a period of considerable complexity, due to understanding the global pandemic (Covid-19). The financial market indices analysed to reveal the instability experienced in these markets in December 2019, February, and March 2020.

Figure 1. Evolution, in levels, of the 5 financial markets, in the full period
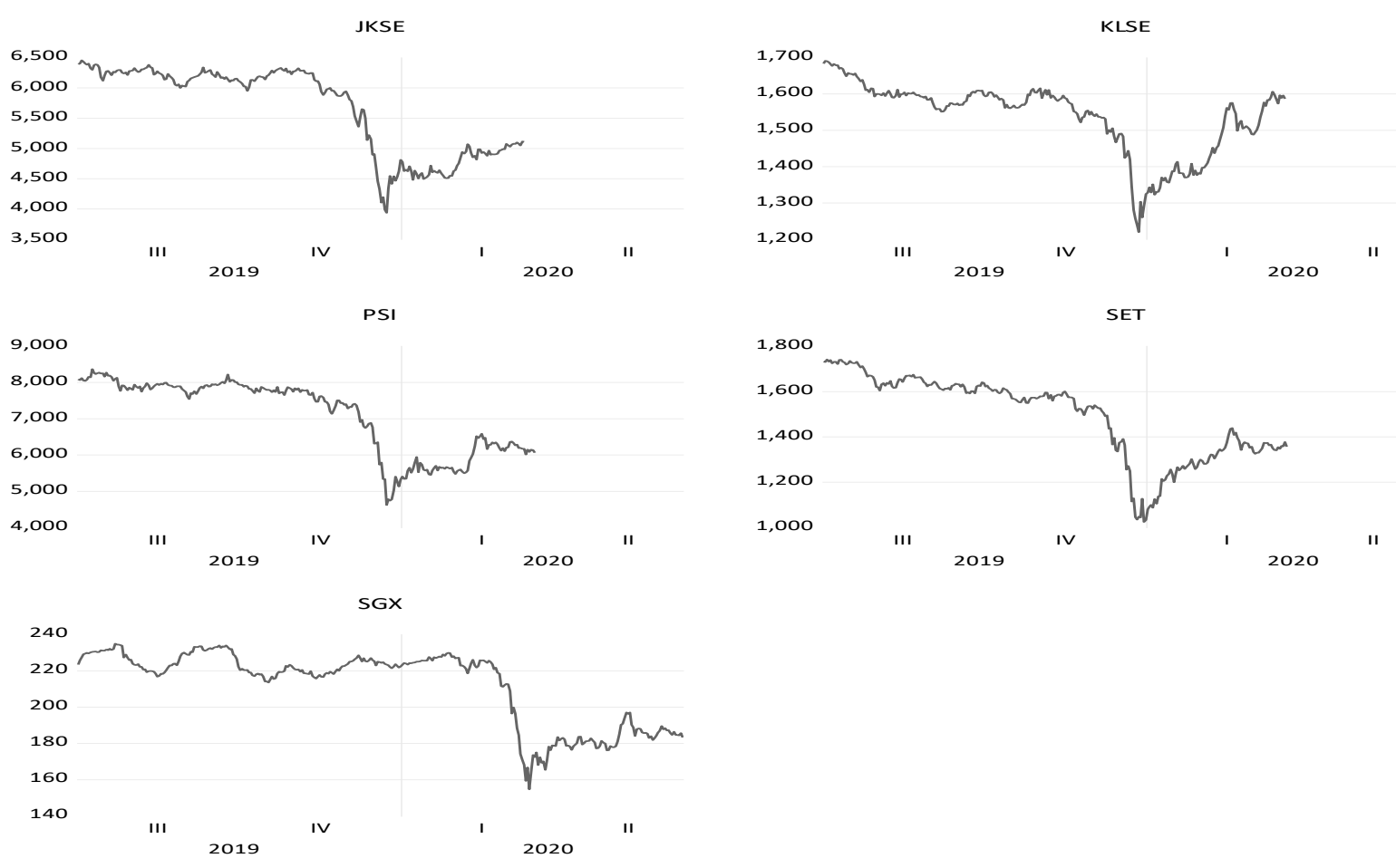

\section{Source: Own elaboration.}

Table 2 shows the main descriptive statistics for the ASEAN-5 markets, referring to the entire period of the sample. The average is negative in these stock indices, while the Philippine market (PSI) has the most accentuated standard deviation. Overall, the coefficients of asymmetry and kurtosis are statistically different from those of a normal distribution, being the same leptokurtic and asymmetric. Jarque-Bera test corroborated this evidence that rejected the null hypothesis, that is, the data series does not follow a normal distribution. 
Table 2. Descriptive statistics, in returns, of the 5 financial markets, in the full period

\begin{tabular}{|l|c|c|c|c|c|}
\hline & JKSE & KLSE & PSI & SET & SGX \\
\hline Mean & -0.000883 & -0.000242 & -0.001066 & -0.000944 & -0.001116 \\
\hline Std. Dev. & 0.015270 & 0.010662 & 0.019986 & 0.017428 & 0.008801 \\
\hline Skewness & 0.306405 & -0.315486 & -2.101792 & -1.915440 & -3.036991 \\
\hline Kurtosis & 12.06136 & 13.01460 & 17.01937 & 17.34357 & 19.30368 \\
\hline Jarque-Bera & $872.9533 * * *$ & $1065.640 * * *$ & $2267.086 * * *$ & $2332.710 * * *$ & $3203.609 * * *$ \\
\hline Sum & -0.224219 & -0.061467 & -0.270806 & -0.239777 & -0.283453 \\
\hline Sum Sq. Dev. & 0.058989 & 0.028762 & 0.101057 & 0.076848 & 0.019597 \\
\hline Observations & 263 & 263 & 263 & 263 & 263 \\
\hline
\end{tabular}

Note: ***.**. represent significance at $1 \%$, respectively.

Source: Own elaboration.

On figure 2 is shown the stability tests performed on the residues of the ASEAN-5 stock indexes, and it is easy to verify the presence of structural breaks. The existence of disturbances in the variance, and the failure to validate structural breaks in the data series, cause biased results in the estimation of the models, that is, there may be evidence of false positives and/or false positives. Also, we can assess the existence of a clear violation of the probability limits, which indicates the presence of stress in these stock markets.

Figure 2. Stability tests carried out on the residues of the ASEN-5 financial markets, in the

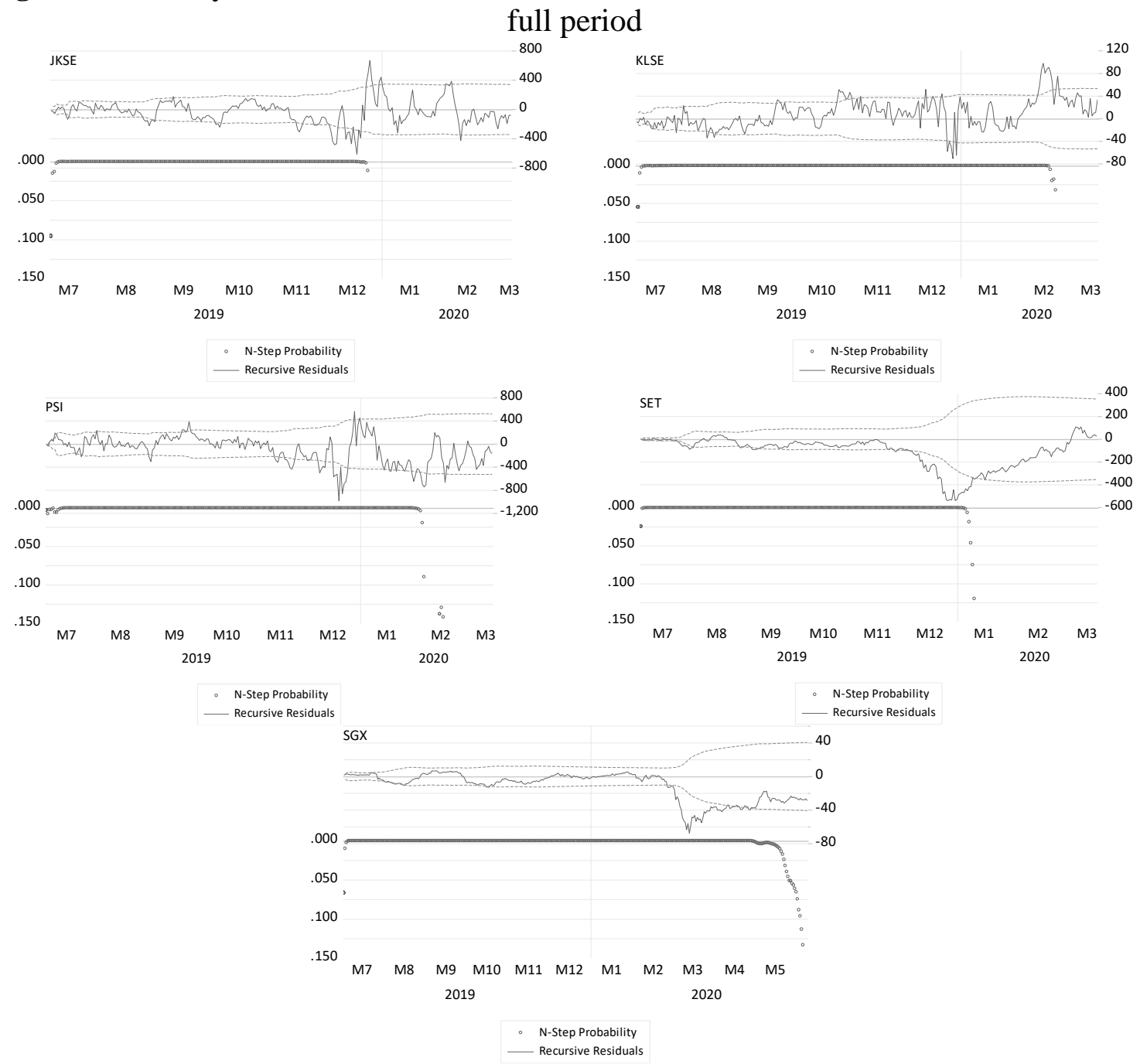

Source: Own elaboration. 
Table 3 shows the results of the test by Clemente et al. (1998) that identifies structure breaks in the ASEAN-5 markets, in December 2019, that is, in the initial phase of the global pandemic (Covid-19), except for the Singapore market (SGX). The results are in line with the findings of the authors Ali, Alam, and Rizvi (2020), Ashraf (2020), which show significant structural breaks resulting from the global pandemic (Covid-19).

Table 3. Unit root tests, with structural breaks, referring to the ASEAN-5 financial markets, in the full period

\begin{tabular}{|c|c|c|}
\hline Index & t-stat & Break Date \\
\hline KLSE & $-17.72(0)^{* * *}$ & $24 / 12 / 2019$ \\
\hline PSI & $-19.22(0)^{* * *}$ & $23 / 12 / 2019$ \\
\hline JKSE & $-15.20(0)^{* * *}$ & $24 / 12 / 2019$ \\
\hline SGX & $-19.01(0)^{* * *}$ & $15 / 03 / 2020$ \\
\hline SET & $-20.19(0)^{* * *}$ & $23 / 12 / 2019$ \\
\hline
\end{tabular}

Note: Lag Length (Automatic Length based on SIC). Break Selection: Minimize Dickey-Fuller t-statistic. The lateral values in parentheses refer to lags. $* * *$.**. *. represent significance at $1 \% .5 \%$ and $10 \%$. respectively.

Source: Own elaboration.

Table 4. Gregory and Hansen integration tests, with structural breaks, referring to the ASEAN-5 financial markets, in the full period

\begin{tabular}{|c|c|c|c|c|c|}
\hline Markets & t-statistic & Method & Lags & Break Date & Results \\
\hline KLSE / PSI & $-4.89^{*}$ & Regime & 2 & $21 / 04 / 2020$ & Integration \\
\hline KLSE / JKSE & $-5.33^{* *}$ & Trend & 5 & $12 / 05 / 2020$ & Integration \\
\hline KLSE / SET & $-5.14 * *$ & Regime & 1 & $27 / 05 / 2020$ & Integration \\
\hline PSI / KLSE & $-5.83^{* * *}$ & Regime & 4 & $27 / 02 / 2020$ & Integration \\
\hline PSI / SGX & $-4.78^{*}$ & Regime & 4 & $27 / 02 / 2020$ & Integration \\
\hline PSI / SET & $-5.87 * * *$ & Trend & 0 & $14 / 04 / 2020$ & Integration \\
\hline JKSE / KLSE & $-6.36^{* * *}$ & Trend & 5 & $21 / 02 / 2020$ & Integration \\
\hline JKSE / PSI & $-6.07 * * *$ & Trend & 2 & $21 / 02 / 2020$ & Integration \\
\hline JKSE / SGX & $-5.11^{*} *$ & Trend & 5 & $21 / 02 / 2020$ & Integration \\
\hline JKSE / SET & $-5.77 * * *$ & Trend & 5 & $20 / 02 / 2020$ & Integration \\
\hline SET / KLSE & $-6.03 * * *$ & Regime & 5 & $27 / 05 / 2020$ & Integration \\
\hline SET / PSI & $-5.51 * * *$ & Regime & 3 & $14 / 04 / 2020$ & Integration \\
\hline SET / JKSE & $-5.15^{* *}$ & Trend & 5 & $16 / 04 / 2020$ & Integration \\
\hline
\end{tabular}

Notes: The AIC information criterion was chosen. The critical values are found in Gregory and Hansen (1996). The asterisks $* * *, * * *$ indicate statistical significance at $1 \%, 5 \%$ and $10 \%$, respectively.

Source: Own elaboration.

Table 4 shows the results of the Gregory-Hansen test (1996), and it is easy to detect 13 pairs of integrated markets (out of 20 possible). The Indonesian market (JKSE) is the stock index that most integrates (4 out of 4 possible), while the markets of Malaysia (KLSE), Philippines (PSI), and Thailand have 3 integrations (out of 4 possible). It should be noted that the Singapore market does not present any integration, which shows evidence regarding the implementation of efficient portfolio diversification strategies. The same can no longer be suggested for the remaining ASEAN-5 markets, which have robust levels of integrations. The breakdowns in the integration structure are different from the breakdowns seen in the markets themselves (December 2019), that is, the breakdowns occur in February, April, and May 2020. Studies corroborate these results by the authors Caporale, Gil -Alana, and Poza (2020), Milos, Hatiegan, Milos, Barna, and Botoc (2020), which show high levels of integration in the stock 
markets, which calls into question the implementation of efficient trading strategies. These findings have important implications for the individual, institutional investors, portfolio managers, and policymakers.

Table 5 shows the results of the $\alpha$ DFA exponents, and we find that the ASEAN-5 markets indicate persistence in profitability, that is, the presence of long accentuated memories, except for the Singapore market (SGX). These findings show that prices do not fully reflect the information available and that changes in prices are not independent and identically distributed. This situation has implications for investors, since some returns can be expected, creating opportunities for arbitrage and abnormal earnings, contrary to assumed by the hypotheses of random walk and informational efficiency. These results are in line with the evidence suggested by the authors Sanusi, Singagerda, and Septarina (2019) that indicate the presence of long memories in the ASEAN markets, which may be beneficial for investors, as these markets show some predictability.

Table 5. DFA exponent for return. The values of the linear adjustments for $\alpha$ DFA always had $R^{2}>0.99$

\begin{tabular}{|c|c|}
\hline Index & DFA exponent (Covid-19) \\
\hline KLSE & $0.60 \cong 0.0019$ \\
\hline PSI & $0.61 \cong 0.0026$ \\
\hline JKSE & $0.60 \cong 0.0013$ \\
\hline SGX & $0.48 \cong 0.0129$ \\
\hline SET & $0.62 \cong 0.0012$ \\
\hline
\end{tabular}

Note: The hypotheses are $H_{0}: \alpha=0.5$ and $H_{1}: \alpha \neq 0.5$

Source: Own elaboration.

In table 6 we can see the cross-correlation coefficients without trend $\lambda_{\text {DCCA }}$, referring to the ASEAN-5 markets, from July 1, 2019, to July 22, 2020. The financial market pairs KLSE-PSI, KLSE-SET, PSI-JKSE, PSI-SET, have strong coefficients $\left(\lambda_{\text {DCCA }}\right)$, while the pairs KLSEJKSE, JKSE-SGX, JKSE-SET and SGX-SET have median correlation coefficients. This evidence may call into question the implementation of efficient portfolio diversification strategies. However, the stock market indices PSI-SGX, KLSE-SGX show a weak/null correlation, that is, the inverse of most markets (see figure 3 ).

Table 6. Summary table of the peaks of $\lambda_{\mathrm{DCC}}$, coefficients, in the ASEAN-5 financial markets, in the full period

\begin{tabular}{|c|c|c|c|c|c|}
\hline Index & Tendency & Time scale (days) & Index & Tendency & Time scale (days) \\
\hline KLSE - PSI & Forte & $\mathrm{n}>16$ & PSI / SGX & Weak & $\mathrm{n}>16$ \\
\hline KLSE - JKSE & Middle & $\mathrm{n}>43$ & PSI / SET & Forte & $\mathrm{n}>16$ \\
\hline KLSE - SGX & Weak & $\mathrm{n}>63$ & JKSE / SGX & Middle & $\mathrm{n}>43$ \\
\hline KLSE - SET & Forte & $\mathrm{n}>43$ & JKSE / SET & Middle & $\mathrm{n}>52$ \\
\hline PSI / JKSE & Forte & $\mathrm{n}>29$ & SGX / SET & Middle & $\mathrm{n}>43$ \\
\hline
\end{tabular}

Source: Own elaboration 
Figure 3. Evolution of the Detrended Cross-Correlation Analysis (DCCA) coefficients, of the ASEAN-5 in the full period
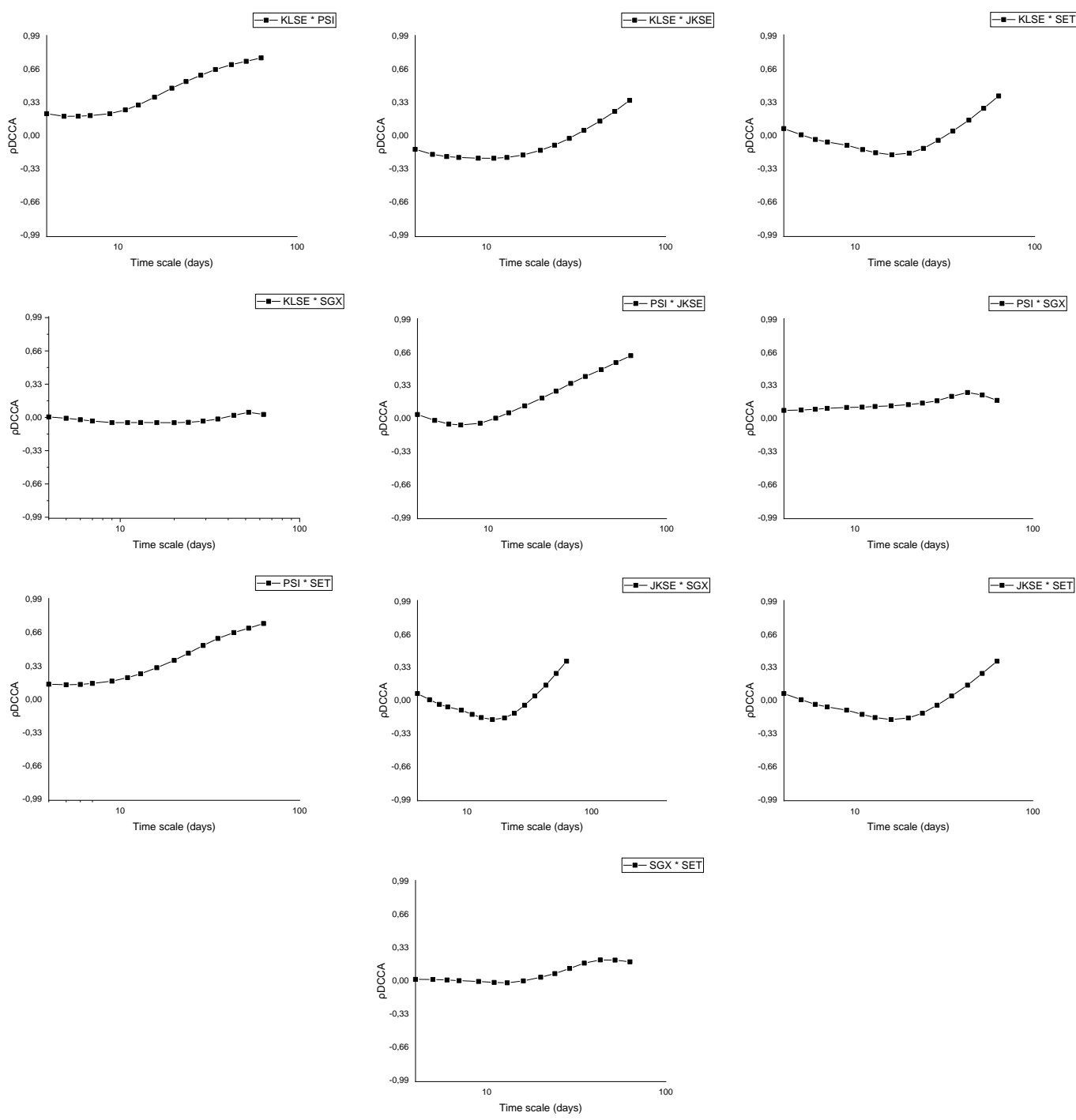

Source: Own elaboration.

\section{CONCLUSION}

The overall conclusion to keep, and sustained on the obtained results, through the tests made with econometric and mathematical models, suggests that these regional markets show high levels of integration. Despite that, Singapore's stock market index does not show any level of integration. In support of this, through the DFA model, we could verify that those regional markets show signs of market inefficiency, in their weak form. This situation brings implications to the investors, considering some returns may be expectable, raising arbitration and abnormal profits opportunities, against what is supposed by the random walk and the international efficiency hypotheses. The crossed correlation coefficient without tendency indicates, on its majority, significant coefficients, suggesting the existence of risk transmission between markets. Concluding, the authors suggest that the implementation of efficient wallet diversification strategies on these markets might be questionable. These conclusions also open a space for these regional markets' regulators to take actions to guarantee a better information exchange between these markets and the international markets. 


\section{REFERENCES}

Ali, M., Alam, N., \& Rizvi, S. A. R. (2020). Coronavirus (COVID-19) - An epidemic or pandemic for financial markets. Journal of Behavioral and Experimental Finance. https://doi.org/10.1016/j.jbef.2020.100341

Alexandre, P., Dias, R., \& Heliodoro, P. (2020a). EUROPEAN FINANCIAL MARKET INTEGRATION: A CLOSER LOOK AT GOVERNMENT BONDS IN EUROZONE COUNTRIES. Balkans Journal of Emerging Trends in Social Sciences, 3(1), 78-86. https://doi.org/10.31410/balkans.jetss.2020.3.1.78-86

Alexandre, P., Dias, R., \& Heliodoro, P. (2020b). HOW LONG IS THE MEMORY OF THE REGION LAC STOCK MARKET? Balkans Journal of Emerging Trends in Social Sciences, 3(2). https://doi.org/10.31410/balkans.jetss.2020.3.2.131-137

Alexandre, P., Heliodoro, P., \& Dias, R. (2019). THE CONTAGION EFFECT IN EUROPE: A DCC GARH APPROACH. In 5th LIMEN Conference Proceedings (part of LIMEN conference collection) (pp. 73-79). https://doi.org/10.31410/limen.2019.73

Ashraf, B. N. (2020). Stock markets' reaction to COVID-19: Cases or fatalities? Research in International Business and Finance. https://doi.org/10.1016/j.ribaf.2020.101249

Auer, R. A., \& Mehrotra, A. (2014). Trade linkages and the globalisation of inflation in Asia and the Pacific. Journal of International Money and Finance. https://doi.org/10.1016/j.jimonfin.2014.05.008

Ben Rejeb, A., \& Boughrara, A. (2015). Financial integration in emerging market economies: Effects on volatility transmission and contagion. Borsa Istanbul Review, 15(3), 161-179. https://doi.org/10.1016/j.bir.2015.04.003

Boubakri, S., \& Guillaumin, C. (2015). Regional integration of the East Asian stock markets: An empirical assessment. Journal of International Money and Finance. https://doi.org/10.1016/j.jimonfin.2015.07.011

Caporale, G. M., Gil-Alana, L. A., \& Poza, C. (2020). High and low prices and the range in the European stock markets: A long-memory approach. Research in International Business and Finance. https://doi.org/10.1016/j.ribaf.2019.101126

Clemente, J., Montañés, A., \& Reyes, M. (1998). Testing for a unit root in variables with a double change in the mean. Economics Letters, 59(2), 175-182. https://doi.org/10.1016/S0165-1765(98)00052-4

Dias, R., da Silva, J. V., \& Dionísio, A. (2019). Financial markets of the LAC region: Does the crisis influence the financial integration? International Review of Financial Analysis, 63(January), 160-173. https://doi.org/10.1016/j.irfa.2019.02.008

Dias, R., Teixeira, N., Machova, V., Pardal, P., Horak, J., \& Vochozka, M. (2020). Random walks and market efficiency tests: Evidence on US, Chinese and European capital markets within the context of the global Covid-19 pandemic. Oeconomia Copernicana, 11(4). https://doi.org/10.24136/OC.2020.024

Dias, R., Alexandre, P., \& Heliodoro, P. (2020). Contagion in the LAC Financial Markets: The Impact of Stock Crises of 2008 and 2010. Littera Scripta, 13(1). https://doi.org/10.36708/littera_scripta2020/1/3

Dias, R., \& Carvalho, L. C. (2020). Hedges and safe havens: An examination of stocks, gold and silver in Latin America's stock market. Revista de Administração Da UFSM, 13(5), 1114-1132. https://doi.org/10.5902/1983465961307

Dias, R., da Silva, J. V., \& Dionísio, A. (2019). Financial markets of the LAC region: Does the crisis influence the financial integration? International Review of Financial Analysis, 63(January), 160-173. https://doi.org/10.1016/j.irfa.2019.02.008

Dias, R., Heliodoro, P., \& Alexandre, P. (2019). Risk transmission among stock markets in LAC Region: financial crises impact, 91-97. 
Dias, R., Heliodoro, P., \& Alexandre, P. (2020a). Efficiency of Asean-5 Markets: An Detrended Fluctuation Analysis. Mednarodno Inovativno Poslovanje = Journal of Innovative Business and Management, 12(2), 13-19. https://doi.org/10.32015/jibm.2020.12.2.13-19

Dias, R., Heliodoro, P., Alexandre, P., Santos, H., \& Farinha, A. (2021). Long memory in stock returns: Evidence from the Eastern European markets. SHS Web of Conferences, 91, 01029. https://doi.org/10.1051/shsconf/20219101029

Dias, R., Heliodoro, P., Alexandre, P., \& Vasco, C. (2020a). FINANCIAL MARKET INTEGRATION OF ASEAN-5 WITH CHINA: AN ECONOPHYSICS APPROACH. In 4th EMAN Conference Proceedings (part of EMAN conference collection). https://doi.org/10.31410/eman.2020.17

Dias, R., Heliodoro, P., Alexandre, P., \& Vasco, C. (2020b). The shocks between oil market to the bric stock markets: A generalized VAR approach, 25-31.

Dias, R., Heliodoro, P., Teixeira, N., \& Godinho, T. (2020c). Testing the Weak Form of Efficient Market Hypothesis: Empirical Evidence from Equity Markets. International Journal of Accounting, Finance and Risk Management, 5(1), 40. https://doi.org/10.11648/j.ijafrm.20200501.14

Dias, R., Pardal, P., Teixeira, N., \& Machová, V. (2020). Financial Market Integration of $\begin{array}{lllll}\text { ASEAN-5 with China. } & \text { Littera }\end{array}$ https://doi.org/10.36708/littera_scripta2020/1/4

Dias, R., \& Pereira, J. M. (2021). The Impact of the COVID-19 Pandemic on Stock Markets. International Journal of Entrepreneurship and Governance in Cognitive Cities, 1(2), 5770. https://doi.org/10.4018/ijegcc.2020070105

Gregory, A. W., \& Hansen, B. E. (1996). Residual-based tests for cointegration in models with regime shifts. Journal of Econometrics, 70(1), 99-126. https://doi.org/10.1016/03044076(69)41685-7

Guedes, E. F., Brito, A. A., Oliveira Filho, F. M., Fernandez, B. F., de Castro, A. P. N., da Silva Filho, A. M., \& Zebende, G. F. (2018). Statistical test for $\triangle \rho D C C A$ : Methods and data. Data in Brief. https://doi.org/10.1016/j.dib.2018.03.080

Gulzar, S., Mujtaba Kayani, G., Xiaofeng, H., Ayub, U., \& Rafique, A. (2019). Financial cointegration and spillover effect of global financial crisis: a study of emerging Asian financial markets. Economic Research-Ekonomska Istrazivanja. https://doi.org/10.1080/1331677X.2018.1550001

He, Q., Liu, J., Wang, S., \& Yu, J. (2020). The impact of COVID-19 on stock markets. Economic and Political Studies. https://doi.org/10.1080/20954816.2020.1757570

Heliodoro, P., Dias, R. \& Alexandre, P. (2020). VARIANCE RATIO TESTS OF THE RANDOM WALK IN THE LAC REGION (pp. 0-76).

Heliodoro, P., Dias, R., \& Alexandre, P. (2020). Financial Contagion Between the Us and Emerging Markets: Covid-19 Pandemic Case. 4th EMAN Selected Papers (Part of EMAN Conference Collection), 1-9. https://doi.org/10.31410/eman.s.p.2020.1

Heliodoro, P., Dias, R., Alexandre, P., \& Vasco, C. (2020). INTEGRATION IN BRIC STOCK MARKETS: AN EMPIRICAL ANALYSIS. In 4th EMAN Selected Papers (part of EMAN conference collection). https://doi.org/10.31410/eman.s.p.2020.33

Hung, N. T. (2019). Return and volatility spillover across equity markets between China and Southeast Asian countries. Journal of Economics, Finance and Administrative Science. https://doi.org/10.1108/JEFAS-10-2018-0106

Jarque, C. M., \& Bera, A. K. (1980). Efficient tests for normality, homoscedasticity and serial independence of regression residuals. Economics Letters, 6(3), 255-259. https://doi.org/10.1016/0165-1765(80)90024-5

Jawadi, F., Chlibi, S., \& Cheffou, A. I. (2019). Computing stock price comovements with a 
three-regime panel smooth transition error correction model. Annals of Operations Research. https://doi.org/10.1007/s10479-018-2805-3

Milos, L. R., Hatiegan, C., Milos, M. C., Barna, F. M., \& Botoc, C. (2020). Multifractal detrended fluctuation analysis (MF-DFA) of stock market indexes. Empirical evidence from seven central and Eastern European markets. Sustainability (Switzerland). https://doi.org/10.3390/su12020535

Moagar-Poladian, S., Clichici, D., \& Stanciu, C. V. (2019). The comovement of exchange rates and stock markets in Central and Eastern Europe. Sustainability (Switzerland). https://doi.org/10.3390/su11143985

Oh, S.-L., Lau, E., Puah, C.-H., \& Abu Mansor, S. (2010). Volatility Co-movement of ASEAN5 Equity Markets. Journal of Advanced Studies in Finance.

Pardal, P., Dias, R., Šuleř, P., Teixeira, N., \& Krulický, T. (2020). Integration in Central European capital markets in the context of the global COVID-19 pandemic, 15(4). https://doi.org/10.24136/eq.2020.027

Peng, C. K., Buldyrev, S. V., Havlin, S., Simons, M., Stanley, H. E., \& Goldberger, A. L. (1994). Mosaic organization of DNA nucleotides. Physical Review E, 49(2), 1685-1689. https://doi.org/10.1103/PhysRevE.49.1685

Petri, P. A., Plummer, M. G., \& Zhai, F. (2012). ASEAN Economic Community: A General Equilibrium Analysis. Asian Economic Journal. https://doi.org/10.1111/j.14678381.2012.02079.x

Podobnik, B., \& Stanley, H. E. (2008). Detrended cross-correlation analysis: A new method for analyzing two nonstationary time series. Physical Review Letters, 100(8). https://doi.org/10.1103/PhysRevLett.100.084102

Salisu, A. A., Ndako, U. B., Adediran, I. A., \& Swaray, R. (2020). A fractional cointegration VAR analysis of Islamic stocks: A global perspective. North American Journal of Economics and Finance. https://doi.org/10.1016/j.najef.2019.101056

Santos, Hortense \& Dias, R. (2020). The Interactions of Stock Prices and Exchange Rates in the ASEAN-5 Countries: The DCCA approach.

Sansa, N. A. (2020). The Impact of the COVID-19 on the Financial Markets: Evidence from China and USA. SSRN Electronic Journal. https://doi.org/10.2139/ssrn.3567901

Sanusi, A., Singagerda, F. S., \& Septarina, L. (2019). The volatility model of the ASEAN Stock Indexes. Investment Management and Financial Innovations. https://doi.org/10.21511/imfi.16(1).2019.18

Wu, F. (2019). Stock market integration in East and Southeast Asia: The role of global factors. International Review of Financial Analysis. https://doi.org/10.1016/j.irfa.2019.101416

Zebende, G. F. (2011). DCCA cross-correlation coefficient: Quantifying level of crosscorrelation. Physica A: Statistical Mechanics and Its Applications, 390(4), 614-618. https://doi.org/10.1016/j.physa.2010.10.022

Zhang, D., Hu, M., \& Ji, Q. (2020). Financial markets under the global pandemic of COVID19. Finance Research Letters. https://doi.org/10.1016/j.frl.2020.101528 